\title{
Physicochemical parameters of arabica fermented coffee in different altitudes
}

\author{
Lucas Louzada Pereira1 (iD), Rogério Carvalho Guarçoni² ${ }^{\text {(D) }}$, Aldemar Polonini Moreli1 (iD), Patrícia Fontes Pinheiro ${ }^{3}$ (D), \\ Carlos Alexandre Pinheiro ${ }^{4}$ (D), Taís Rizzo Moreira ${ }^{5}$ (D), Evandro de Andrade Siqueira ${ }^{1}$ (D), Carla Schwengber ten Caten $^{6}$ (iD)
}

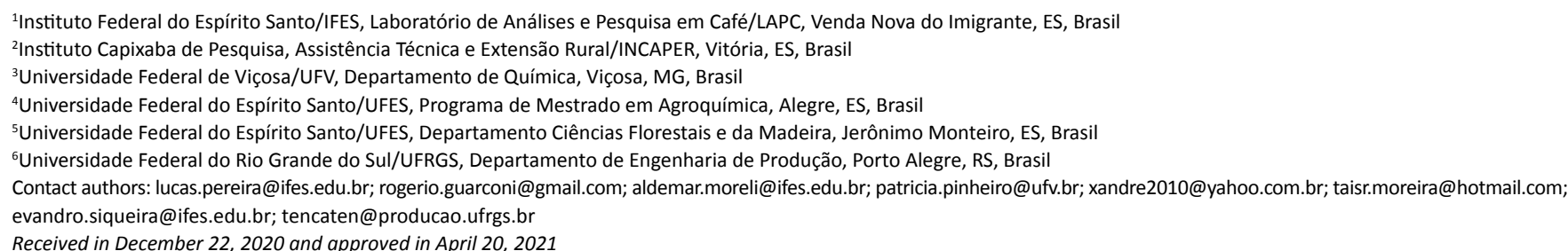

\section{ABSTRACT}

The coffee quality interacts with different processes, techniques, analyses, and concepts. This study applied six different forms of wet fermentation to coffee from different altitude ranges to understand how coffee quality interacts with the physicochemical profile and its possible relations with sensory variables. Statistical analysis was performed through combined analyses of variance of the experiments, and the means were compared by the Tukey test considering the significance level of $5 \%$. Regression models were tested by the $F$-test and the parameters by the $t$-test, followed by Pearson correlation analysis between the sensory and physicochemical characteristics and between physicochemical variables. The results indicate a correlation between sensory and physicochemical variables for total titratable acidity and indicate that these compounds are affected by the manner of fermentation applied as well as the edaphic and climatic conditions.

Key words: Coffea arabica; Chemical interaction; Fermentation; Processing.

\section{INTRODUCTION}

Coffee quality is affected by several factors in the pre- and post-harvest stages that interact with the coffee bean; such factors may be genetic composition (Scholz et al., 2013), altitude (Joët et al., 2010), the processing method, the microorganisms present in processing during the post-harvest stage, and the procedures adopted at the industrialization stage (Ribeiro et al., 2014).

There are two methods of post-harvest processing: in one of them the fruit remains intact and is commonly called natural coffee (via the dry processing method); in the other, fruit pulp is removed (via the wet processing method) (Reinato et al., 2012). When done correctly, the wet processing method ensures that the intrinsic qualities of the coffee beans are preserved for a prolonged period, producing a homogenous coffee with few defective beans (Lin, 2010).

In addition to the effects of wet processing on coffee attributes are the effects of altitude. Coffees from higher altitude regions receive higher sensory scores (mainly for attributes related to flavor, aroma, sweetness, and body) than coffees from warmer regions (Da Matta, 2004; Joët et al., 2010). This can be associated at high altitudes with low temperatures and no nutrient or water deficits, shade trees may thus have a partly adverse effect on Coffea arabica, resulting in reduced sensory quality (Bosselmann et al., 2009). (Bosselmann et al., 2009).
When this translocation occurs, it constitutes a natural terroir of these microregions. Although shading and altitude are empirically known to have beneficial effects on coffee quality, only a few scientific studies have documented these effects (Joët et al., 2010).

Furthermore, the effect of microorganisms during the post-harvest processing stage, microorganisms such as bacteria (De Melo et al., 2014), yeasts, and fungi (Evangelista et al., 2014; Velmourougane, 2013), has been associated with their ability to promote metabolic actions through anabolic or catabolic processes, given that certain attributes can be optimized through use of these microorganisms (Lee et al., 2015).

Physicochemical factors are among those evaluated in coffee quality, and the most cited in the literature are titratable acidity, $\mathrm{pH}$, and phenolic compounds. This last factor is abundant in coffee, cocoa, wine, and tea (Corrêa et al., 2015); these compounds contribute to the characteristic flavor and aroma of the coffee beverage (Abrahão et al., 2010). In addition, the acidity of the coffee and the $\mathrm{pH}$ are indicators of possible transformations of the coffee fruit, along with desirable or undesirable fermentations that occur in the period before harvest or in post-harvest (Clarke; Vitzthum, 2008; Siqueira; Abreu, 2006).

Correlations among data from chemical and sensory analyses of coffee beans are not always effective in 
discriminating quality; however, there may be opportunity to summarize large groups of data, reducing their dimensionality and allowing for combined interpretations of the variables involved in the study (Clemente et al., 2015).

This study used four different forms of fermentation for Arabica coffee from different altitudes, with a focus on understanding the physicochemical response and possible correlation with sensory descriptors for greater understanding of beverage quality.

\section{MATERIAL AND METHODS}

\subsection{Experimental planning}

The experimental material was obtained from coffee grown at altitudes of 774, 788, 893, 907, 1004, and 1033 meters and the experiment was carried out in a randomized block design with five replicates. The processing methods were washed fermentation - fermentation with water, yeast fermentation - fermentation of yeast culture, fully washed (pulped and demucilaged by fermentation), and semi-dry - and dried with remaining mucilage.

\subsection{Harvesting fruit for the experiments}

Coffees of the Catuaí Vermelho variety were harvested by growers in experiments from June to October 2016. The coffees were harvested at $85 \%$ maturity to perform wet processing. Floaters and unripe fruit were discarded. The experiments carried out at altitudes 774; 788; 893; 907; 1004 and 1033 were conducted from a randomized block design with five replications, with the methods consisting of fermentation in a Washed process: fermentation with water, Yeast Fermentation: fermentation with yeast culture, Fully Washed: dry (peeled and demucilated cherry by means of fermentation) and Semi-dry: peeled and dried with residual mucilage.

\subsection{Raw materials applied in wet processing}

The raw materials used in the formulation of the must were: coffee pulp, cascara from the coffee, water, and yeast (Saccharomyces cerevisiae $s p$ ). $15 \mathrm{~kg}$ of coffee were harvested per experimental plot. The fruits were processed according to the treatments.

1- Washed: must of fermentation with water (washed), $10 \mathrm{~kg}$ of pulped coffee cherry (pulp), $5 \mathrm{~kg}$ of cascara, and $0.005 \mathrm{~m}^{3}$ of water.

2- Yeast fermentation: fermenting must with a yeast starter culture (Saccharomyces cerevisiae), in the proportion of $10^{7}$ $(\mathrm{p} / \mathrm{v})$ of the must, $10 \mathrm{~kg}$ of pulped coffee cherry (pulp), $5 \mathrm{~kg}$ of cascara, $0.005 \mathrm{~m}^{3}$ water, patent process BR1020160040531. 3- Fully washed: fermentation must without water (fully washed), $10 \mathrm{~kg}$ of pulped coffee cherry, and $5 \mathrm{~kg}$ of cascara, without adding water to the process.
4- Semi-dry: pulped coffee without mucilage removal (semidry), without any addition of microorganisms.

Musts 1 and 2 had water added to the processing at a temperature of $311 \mathrm{~K}$ with adjustment to the methods of Pereira et al. (2020) and remained immersed for 36 hours in fermentation tanks in the processing laboratory of the Federal Institute of Espírito Santo (IFES), in Venda Nova do Imigrante. Must 3 received only cascara and pulped coffee from wet processing and remained in the fermentation process for 36 hours. Must 4 was taken to dry on a covered terrace immediately after the peeling process. After the fermentation period, musts 1,2 , and 3 were washed and taken to dry in a suspended, covered terrace. The described methods were proposed and validated by Pereira et al. (2020).

\subsection{Sensory analysis via SCA protocol}

The samples were performed following the recommendations of the Specialty Coffee Association. After 8 to $24 \mathrm{~h}$ after roosting process, the coffee was ground in a disc mill (Bunn Coffee Mill, model G3A HD), with granulometry between 70 and $75 \%$ of the particles passing through a sieve 20 mesh, US Standards. The sensory analysis panel were evaluated by 6 Q-graders, according to Pereira et al. (2018). The infusion point of water was performed after the water reached $92-95{ }^{\circ} \mathrm{C}$. The Q-Graders began the evaluations when the temperature of the cups reached $55^{\circ} \mathrm{C}$, respecting the time of 4 minutes for the tasting after the infusion. Thus, the SCAA protocol considers the following variables to perform the descriptive sensory analysis: Fragrance/Aroma, Flavor, Aftertaste, Acidity, Body, Balance, Sweetness, Clean Cup, Uniformity, Overall and Final Score.

\subsection{Sample preparation for sensory analysis}

The samples were prepared in the coffee sensory analysis laboratory of the Instituto Federal do Espírito Santo (Ifes) in Venda Nova do Imigrante, ES, Brazil, according to the methodology of the Specialty Coffee Association (SCA). Coffee was roasted using the Laboratto TGP-2 roaster with the Agtron-SCAA disc set; the roasting point of these samples was within the colors determined by disks \#65 and \#55 for specialty coffees (Specialty Coffee Association of American - SCAA, 2013).

Coffee was roasted 24 hours in advance and grinding was in conformity with an 8-hour resting time after roasting. All samples were roasted from 9 to 10 minutes and after roasting and cooling, the samples remained sealed, according to the sensory analysis methodology established by the SCA.

The coffee samples were ground with a Bunn G3 electric grinder, with medium/coarse particle size. Within the 
period of 8 to 24 hours after roasting, the coffee was ground in a disk mill (Bunn Coffee Mill, model G3A HD) so that $70 \%$ to $75 \%$ of the particles passed through a 20 mesh sieve, US Standards (SCAA, 2013). Each sample of coffee was tasted with 5 cups, using a concentration of $0.00825 \mathrm{~kg}$ of ground coffee in $0.00015 \mathrm{~m}^{3}$ of water according to the midpoint of the balance graph, a concentration which is optimal for attaining the Golden Cup standard (SCAA, 2013). Water was infused after reaching 365-368 K. The Q-Graders initiated assessments when the temperature of the beverage reached $328 \mathrm{~K}$, tasting at 4 minutes after infusion.

\subsection{Preparation of samples to perform physicochemical analyses}

After the sensory analysis test verifying beverage quality, physicochemical analysis was performed on the roasted beans. The coffee beans were ground in a fine-grain Bunn Coffee Mill, model G3A HD so that $70 \%$ to $75 \%$ of the particles passed through a $0.074 \mathrm{~mm}-\mathrm{mesh}$ sieve, US Standard $281 \mathrm{~K}$.

\subsection{Analysis of $\mathrm{pH}$ and titratable acidity.}

The extract used to obtain the $\mathrm{pH}$ and the titratable acidity was prepared from $0.002 \mathrm{~kg}$ of ground coffee diluted in $0.00005 \mathrm{~m}^{3}$ of distilled water and stirred for 1 hour on a mechanical stirrer at $150 \mathrm{rpm}$. The extract solution was filtered through a quantitative paper filter and the $\mathrm{pH}$ was measured by a digital $\mathrm{pH}$ meter. A $0.000005 \mathrm{~m}^{3}$ aliquot of the filtrate was diluted in $0.00005 \mathrm{~m}^{3}$ of distilled water. Total titratable acidity was determined by titration with $0.1 \mathrm{~N} \mathrm{NaOH}$ using $2-3$ drops of a $1 \%$ phenolphthalein solution as an indicator and expressed in $\mathrm{mL}$ of $0.1 \mathrm{~N} \mathrm{NaOH}$ per $0.1 \mathrm{~kg}$ of sample (Association of Official Analytical Chemists - AOAC, 1990).

\subsection{Total phenolic compounds}

Total phenolic compounds was determined using the Folin-Ciocalteu method (Morais, 2009). Initially, an extract of $0.002 \mathrm{~kg}$ of ground coffee with $0.00001 \mathrm{~m}^{3}$ of boiling water was prepared, leaving it to infuse under heating for one minute. After this procedure, $1.10^{-7} \mathrm{~m}^{3}$ of this extract was pipetted, which was diluted with water to a volume of $0.00005 \mathrm{~m}^{3}$. From this solution, a $5.10^{-7} \mathrm{~m}^{3}$ aliquot was taken and transferred to a test tube. Then, $2.5 .10^{-6} \mathrm{~m}^{3}$ of a $10 \%$ aqueous solution of the Folin-Ciocalteu reagent and $2.10^{-6} \mathrm{~m}^{3}$ of a $7.5 \%$ sodium carbonate solution were added. The mixture was kept in a water bath at a temperature of $50{ }^{\circ} \mathrm{C}$ for 5 minutes. After the sample had cooled, absorbance was measured at $760 \mathrm{~nm}$. Together with the samples, a calibration curve of aqueous solutions with known concentrations was prepared, using gallic acid as a standard. The result was expressed in ranges of gallic acid equivalent per $0.1 \mathrm{~kg}$ of a dry coffee sample.

\subsection{Statistical analysis}

For statistical analysis, combined analysis of variance of the experiments was performed for the physicochemical (phenolic compounds, total titratable acidity, and $\mathrm{pH}$ ) and sensory results, and the means were compared by the Tukey test considering the significance level of 5\%. Regression models were tested by the $F$-test and the parameters by the $t$-test. Pearson correlation analyses were performed between sensory and physicochemical characteristics. In addition, dendrograms were constructed using the average Euclidean distance to measure the distances between the sensory analysis clusters, followed by physicochemical data. The R Core Team (2019) software was used for statistical analyses.

\section{RESULTS}

The analysis of phenolic compounds, total titratable acidity, and $\mathrm{pH}$ are shown in Table 1. For these phenolic compounds, no significant functional correlations were observed between phenolic components and altitude, acidity, and altitude, and between $\mathrm{pH}$ and altitude, for any of the four methods.

The parameter of physicochemical analyses was applied in studies by Malta, Santos and Melo Silva (2002), Siqueira and Abreu (2006), and Somporn et al. (2012) in an attempt to correlate the compounds mentioned with overall coffee beverage quality. Thus results for lower-quality coffees have higher levels of phenolic compounds; however, in the studies cited, these results are relatively divergent, thus reinforcing the need to understand in detail the chemical matrix of coffee and how these compounds can alter the final composition of the beverage. In addition to this fact, these results indicate the need to expand and understand the physical and chemical parameters of coffee, with the application of more tough techniques.

The results regarding correlation between sensory and physicochemical variables are shown in Table 2, the results showed no significant correlations between the sensory variables and $\mathrm{pH}$.

The increase in $\mathrm{pH}$ is associated with increased titratable acidity of the coffee, as shown in Table 3.

Finally, the dendrogram of Figure 1 suggests the existence of three homogenous groups: group A formed by points (altitude/treatment) 1, 2, 3, 4, 13, 14, 15, 16, and 21; group B formed by points 17, 22, and 23; and group C formed by the other points.

\section{DISCUSSION}

The division of the discussion into the topics that follow is based on the results presented above. 
Table 1: Analysis of phenolic compounds, total titratable acidity, and pH of material (coffee) obtained from experiments at altitudes of $774,788,893,907,1004$, and 1033 meters.

\begin{tabular}{|c|c|c|c|c|c|c|c|c|}
\hline \multicolumn{9}{|c|}{ Characteristics of compounds in coffee beans from the altitude ranges studied } \\
\hline & \multirow{2}{*}{ Method } & \multicolumn{6}{|c|}{ Altitude (m) } & \multirow{2}{*}{ Means } \\
\hline & & 774 & 788 & 893 & 907 & 1004 & 1033 & \\
\hline \multirow{5}{*}{ Phenolic } & Washed & $4.99 \mathrm{a}$ & $6.28 \mathrm{a}$ & $5.15 \mathrm{a}$ & $4.87 \mathrm{a}$ & $5.66 \mathrm{a}$ & $4.77 \mathrm{~b}$ & $5.29 \mathrm{~b}$ \\
\hline & Yeast Ferm. & $5.23 \mathrm{a}$ & $5.65 \mathrm{a}$ & $5.75 \mathrm{a}$ & $5.13 \mathrm{a}$ & $5.41 \mathrm{a}$ & $6.01 \mathrm{a}$ & $5.53 \mathrm{ab}$ \\
\hline & Fully washed & $5.06 \mathrm{a}$ & $5.64 \mathrm{a}$ & $5.56 \mathrm{a}$ & $4.97 \mathrm{a}$ & $5.43 \mathrm{a}$ & $5.52 \mathrm{a}$ & $5.36 \mathrm{ab}$ \\
\hline & Semi-dry & $5.55 \mathrm{a}$ & $5.81 \mathrm{a}$ & $5.33 \mathrm{a}$ & $5.11 \mathrm{a}$ & $5.70 \mathrm{a}$ & $5.93 \mathrm{a}$ & $5.57 \mathrm{a}$ \\
\hline & Means & 5.21 & 5.84 & 5.45 & 5.02 & 5.55 & 5.56 & \\
\hline \multirow{4}{*}{ Titratable acidity } & Washed & $284.84 \mathrm{~b}$ & $232.30 \mathrm{a}$ & $234.28 \mathrm{bc}$ & $234.11 \mathrm{c}$ & $316.91 \mathrm{a}$ & $254.32 \mathrm{c}$ & $259.46 \mathrm{~b}$ \\
\hline & Yeast Ferm. & $295.76 \mathrm{a}$ & $234.36 \mathrm{a}$ & $238.18 \mathrm{ab}$ & $259.99 \mathrm{~b}$ & $270.18 \mathrm{c}$ & $270.69 \mathrm{~b}$ & $261.53 \mathrm{~b}$ \\
\hline & Fully washed & $296.81 \mathrm{a}$ & $238.57 \mathrm{a}$ & $243.62 \mathrm{a}$ & $240.22 \mathrm{c}$ & $253.74 \mathrm{~d}$ & $262.58 \mathrm{bc}$ & $255.92 \mathrm{c}$ \\
\hline & Means & 291.78 & 235.34 & 235.59 & 251.58 & 282.93 & 269.78 & \\
\hline \multirow{5}{*}{ Coffee $\mathrm{pH}$} & Washed & $5.22 \mathrm{a}$ & $5.07 \mathrm{a}$ & $5.02 \mathrm{~b}$ & $5.09 \mathrm{~b}$ & $5.25 \mathrm{a}$ & $5.16 \mathrm{c}$ & $5.14 \mathrm{a}$ \\
\hline & Yeast Ferm. & $5.08 \mathrm{c}$ & $5.06 \mathrm{ab}$ & $5.12 \mathrm{a}$ & $5.13 \mathrm{ab}$ & $5.02 \mathrm{c}$ & $5.27 \mathrm{~b}$ & $5.11 \mathrm{~b}$ \\
\hline & Fully washed & $5.15 \mathrm{~b}$ & $5.02 \mathrm{~b}$ & $4.95 \mathrm{c}$ & $5.16 \mathrm{a}$ & $5.12 b$ & $5.37 \mathrm{a}$ & $5.13 \mathrm{ab}$ \\
\hline & Semi-dry & $5.17 \mathrm{~b}$ & $5.06 \mathrm{ab}$ & $5.03 \mathrm{~b}$ & $5.12 \mathrm{~b}$ & $5.00 \mathrm{c}$ & $5.07 \mathrm{~d}$ & $5.07 \mathrm{c}$ \\
\hline & Means & 5.15 & 5.05 & 5.03 & 5.13 & 5.10 & 5.22 & \\
\hline
\end{tabular}

${ }^{1}$ Phenolic compounds $=\mathrm{g}$ of gallic acid equivalent per $100 \mathrm{~g}$ of dry coffee sample.

2 Total Titratable Acidity $=\mathrm{mL} 0.1 \mathrm{~N} \mathrm{NaOH} .100 \mathrm{~g}^{-1}$ of sample.

${ }^{3}$ Coffee $\mathrm{pH}=$ Values (\%) based on AOAC (1990).

${ }^{4}$ Means followed by the same letter in the column do not differ by Tukey's test at $5 \%$ probability.

Source: The author.

Table 2: Pearson correlation coefficients between sensory and physicochemical variables.

\begin{tabular}{ccccc}
\hline & & \multicolumn{3}{c}{ Physicochemical variables } \\
\cline { 2 - 5 } Sensory Variable & $\begin{array}{c}\text { Phenolic } \\
\text { Compounds }\end{array}$ & $\begin{array}{c}\text { Total } \\
\text { Titratable } \\
\text { Acidity }\end{array}$ & $\mathrm{pH}$ \\
\hline Fragrance/Aroma & 7.50 & $0.0379^{\text {ns }}$ & $0.2232^{* *}$ & $0.0559^{\mathrm{ns}}$ \\
Flavor & 7.55 & $-0.0078^{\mathrm{ns}}$ & $0.2292^{* *}$ & $-0.0217^{\mathrm{ns}}$ \\
Aftertaste & 7.26 & $-0.0339^{\mathrm{ns}}$ & $0.3215^{* *}$ & $0.0247^{\mathrm{ns}}$ \\
Acidity & 7.39 & $0.0198^{\mathrm{ns}}$ & $0.3104^{* *}$ & $0.0472^{\mathrm{ns}}$ \\
Body & 7.37 & $0.0345^{\mathrm{ns}}$ & $0.3139^{* *}$ & $0.0328^{\mathrm{ns}}$ \\
Balance & 7.50 & $-0.0285^{\mathrm{ns}}$ & $0.3205^{* *}$ & $0.0359^{\mathrm{ns}}$ \\
Global Score & 82.04 & $0.0306^{\mathrm{ns}}$ & $0.2468^{* *}$ & $0.0054^{\mathrm{ns}}$ \\
Overall & 7.50 & $0.0051^{\mathrm{ns}}$ & $0.2984^{* *}$ & $0.0336^{\mathrm{ns}}$ \\
\hline
\end{tabular}

Source: the author.

* and **: significant at $5 \%$ and $1 \%$ probability, respectively; ns: not significant.

\subsection{Phenolic compounds}

Comparing the results for means of the total phenolic compounds for each altitude individually, it is clear that the processes differ only in the experimental altitude of $1033 \mathrm{~m}$.
The washed fermentation process differs from the other methods $(p>0.05)$. However, when analyzing the average of experiments, the semi-dry method is higher value to the washed method, although it does not differ $(p>0.05)$ from the yeast fermentation and fully washed methods.

Table 3: Pearson correlation coefficients between physicochemical variables.

\begin{tabular}{ccc}
\hline Variable & TTA & $\mathrm{pH}$ \\
\hline Phenolic Compounds & $-0.0056^{\text {ns }}$ & $-0.0912^{\text {ns }}$ \\
TTA & & $0.3452^{* *}$ \\
\hline
\end{tabular}

Source: the author.

${ }^{*}$ and ${ }^{* *}$ : significant at $5 \%$ and $1 \%$ probability, respectively; ns: not significant.

During the roasting process, these phenolic compounds are intensely degraded, resulting in pigments and volatile components that create coffee aroma. The phenolic compounds in the product after roasting can be associated with the astringency of the beverage (Duarte; Pereira; Farah, 2010). The results obtained in this study corroborate those of Malta, Santos and Melo Silva (2002), in which the authors found a difference in phenolic compounds (average values) between arabica coffee cultivars. 


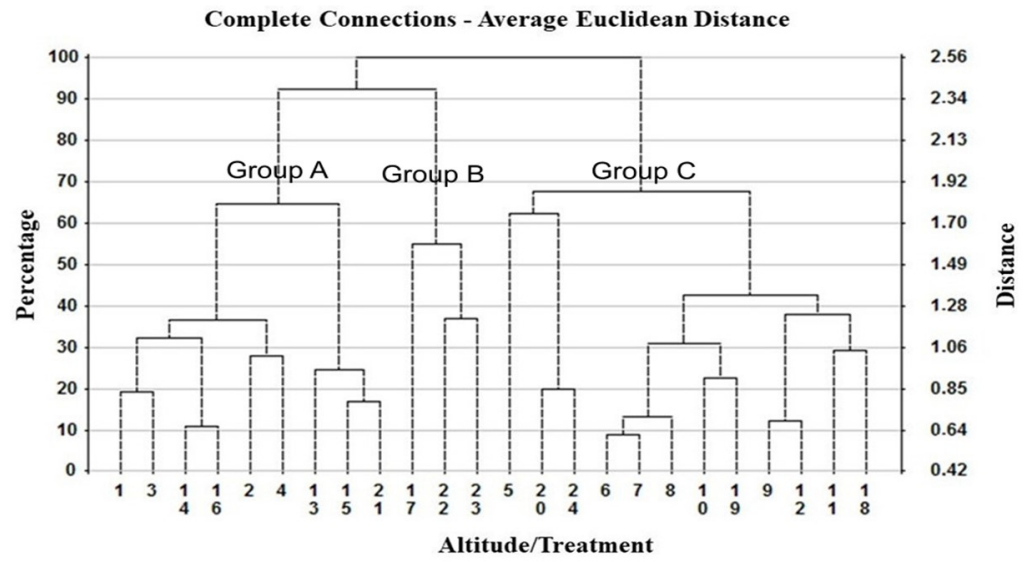

Figure 1: Dendrogram with 24 points (6 altitudes and 4 methods) referring to the physicochemical composition of phenolic compounds, total titratable acidity, and $\mathrm{pH}$, according to the different processing/fermentation methods used.

In a study by Siqueira and Abreu (2006), the values of the phenolic compounds did not differ significantly among three types of processing. The results observed in Table 1 do not support the results presented by the authors, but indicate that phenolic compounds show differences among the types of processing in the experiments.

Pinto et al. (2001) and Abrahão et al. (2010) state that there is evidence of a higher concentration of total phenolic compounds in poorer-quality coffees. In contrast, Fernandes et al. (2003) found polyphenol content of $4.31 \%$ in arabica duro (hard) coffee and, in the same study, the authors indicate that the riada (rio-ish) coffee beverage had high values, $6.18 \%$ of total phenolic compounds. Thus, the results presented in Table 1 indicate statistical differences $(p<0.05)$ among the processing methods when analyzing the means of combined analysis. The results suggest that the values found are not related to low-quality coffees. All coffee samples were considered specialty coffees by the SCA methodology.

The results indicate a new interpretation: that phenolic compounds alone, quantified in percentages, cannot define the quality of a coffee, given its chemical complexity, since these compounds can produce lactones or quinides by degradation during roasting, due to the pyrolysis reaction (Farah et al., 2005). Lactones are linked to the aromatic compounds of coffee (Ramos et al., 2009). Although the relevance of quinides in aroma precursors is known, little is known about their real impact on coffee (Ferrão et al., 2003).

The measures of analysis of total phenolic compounds may be better dismembered by understanding chlorogenic acid, or that the analyses are linked to the fermentation of coffee (Bonilla-Hermosa; Duarte; Schwan, 2014). Thus, it would be possible to infer how phenolic compounds act on quality, based on the history and monitoring of wet fermentation and based on climatic factors.

\subsection{Total titratable acidity - TTA}

Although it is not clear which compounds are responsible for the perceived acidity, it is known that citric, malic, acetic, quinic, and, mainly, chlorogenic acids are responsible in large part for the organoleptic characteristics of coffee (Clarke; Vitzthum, 2008).

For total titratable acidity, the results indicate that for coffee grown at the altitude of $774 \mathrm{~m}$, the yeast fermentation and fully washed methods do not differ $(p<0.05)$ from the semi-dry method, but differ from the washed method ( $p$ $>0.05)$, and the washed and semi-dry methods have no difference $(p>0.05)$ between them. For the altitude of $788 \mathrm{~m}$, the methods showed no differences $(p>0.05)$. For the altitude of $893 \mathrm{~m}$, the fully washed and yeast fermentation methods do not differ $(p>0.05)$ from each other, but are superior to the semi-dry method $(p<0.05)$. For the altitude of $907 \mathrm{~m}$, the semi-dry method differs $(p<0.05)$ from all others, the yeast fermentation method differs from the washed and fully washed methods $(p<0.05)$, and the washed and fully washed methods do not differ $(p>0.05)$.

For the second highest altitude, $1004 \mathrm{~m}$, all methods show statistical differences $(p<0.05)$, with the washed method having the highest TTA values. Finally, for the greatest height, at an altitude of $1033 \mathrm{~m}$, the semi-dry method differs from all others $(p<0.05)$ and has the highest TTA value for that altitude; the yeast fermentation and fully washed methods do not differ statistically; and the washed and fully washed methods also do not differ $(p>0.05)$.

The general results of analyses of titratable acidity were different from the results cited in the literature (Fernandes et al., 2003; Siqueira; Abreu, 2006; Ferreira et al., 2011); in those studies, the researchers did not observe TTA differences among the coffees that were wet processed. However, the results of this study corroborate those of Malta, Santos and Melo Silva (2002), in which the authors find differences in the levels of total titratable acidity. 
The minimum value found for total titratable acidity for the variety Catuaí Vermelho was $0.00022629 \mathrm{~m}^{3}$ and the maximum value observed was $0.00031691 \mathrm{~m}^{3}$, among the six altitude ranges studied in the experiments of this work. These data are in accordance with the values described by Malta, Santos and Melo Silva (2002).

\section{3 pH results of the coffee samples studied}

The $\mathrm{pH}$, by definition, represents hydrogen potential and is estimated on a logarithmic scale to measure the degree of acidity, neutrality, or alkalinity of a given solution. The $\mathrm{pH}$ values ranged from 4.95 to 5.37 , outside the range of commercial coffees recommended by the International Coffee Organization - ICO (1992); however, they agree with the values found by Scholz et al. (2011). According to Fernandes et al. (2003), pH variations are extremely important in consumer acceptance of the product, and the authors indicate that the ideal $\mathrm{pH}$ ranges from 4.95 to 5.20 to make the coffee palatable.

For the $774 \mathrm{~m}$ experimental altitude, the washed method differs from all other methods ( $p<0.05)$, indicating that it has a higher $\mathrm{pH}$ for this altitude than the other methods, followed by the fully washed and semi-dry methods, which have no statistical difference $(p>0.05)$; and the yeast fermentation method exhibited the most acidic $\mathrm{pH}$.

The experiment at the $788 \mathrm{~m}$ altitude shows a statistical difference between the washed and fully washed method; however, the washed method does not differ from the yeast fermentation and semi-dry methods $(p>0.05)$. In coffee from the $893 \mathrm{~m}$ altitude, the yeast fermentation method is different $(p<0.05)$ from all other methods, with higher $\mathrm{pH}$; and the washed and semi-dry methods have no differences between them, but differ from the fully-washed method $(p<0.05)$.

In the fourth altitude level, $907 \mathrm{~m}$, the yeast fermentation and fully-washed methods have no statistical difference between them, and the fully washed method has a $\mathrm{pH}$ higher than the washed and semi-dry methods. The yeast fermentation method does not differ from the washed and semidry methods $(p>0.05)$. At the second highest experimental altitude, the washed method has a higher $\mathrm{pH}$ than the others, followed by the fully washed method, which differs from the yeast fermentation and semi-dry methods; and the latter two methods did not show statistical differences $(p>0.05)$.

At the highest experimental altitude, all methods show statistical differences from each other $(p<0.05)$, with the fully washed method having the highest $\mathrm{pH}$ value, followed by the yeast fermentation, washed, and semi-dry methods.

The mean values obtained in the experiments show that there are no statistical differences between the washed and fully washed methods; however, the washed method differs from the methods other than the fully washed method ( $p<$ $0.05)$, and the semi-dry method has the lowest $\mathrm{pH}$ value.
For Masoud and Jespersen (2006), during yeast fermentation, the $\mathrm{pH}$ values range from 5.5 to 5.0, which agrees with the data from this study. According to Nasanit and Satayawut (2015), the $\mathrm{pH}$ can gradually decrease during the fermentation period from 6.27 to 4.00 , depending on the type of yeast that is added to the coffee fermentation solution. This indicator reinforces the results obtained from the coffees grown at the altitudes of 774 and $1033 \mathrm{~m}$, where the application of yeasts modified the $\mathrm{pH}$ levels compared to the other methods.

Monitoring of $\mathrm{pH}$ can be used to accelerate the transition from one stage of a fermentation process to another (aerobic and anaerobic), changing fermentation conditions, such as temperature, $\mathrm{pH}$, and must composition, increasing or suppressing the growth of some microorganisms to give more consistency to the fermentation process (Sandhya et al., 2016). In addition, some of the microbial interactions that occur in fermentations are characterized by the fact that some microorganisms create stressful conditions for others; for example, they compete for nutrients and/or produce inhibitory metabolites (Schwan; Fleet, 2014).

There is an indication that acidity should increase and $\mathrm{pH}$ should decrease as coffee quality decreases (Franca; Mendonça; Oliveira, 2005). However, the same authors did not detect significant differences between hard bean and rio coffee treatments in their studies. These indications in the literature correlate with the results of the present experiments since all the sensory-evaluated coffees have specialty coffee scores, above the 80 points proposed by the SCAA protocol. However, Gloess et al. (2013) found no correlation between the $\mathrm{pH}$ or the titratable acidity values with the sensory aspect of the coffees evaluated in Guatemala, and did not show correlations between an increase in acidity and a decline in quality.

Wang et al. (2016) reported that the $\mathrm{pH}$ and the titratable acidity of arabica coffee have a significant correlation with the acidity of the coffee beverage perceived through sensory analysis. Silva et al. (2016) reported that the Catuaí Vermelho 144 variety showed a correlation between titratable acidity and $\mathrm{pH}$ with coffee quality.

However, significant correlations were observed at a $1 \%$ probability between Total Titratable Acidity (TTA) and all sensory attributes of the SCA protocol. The data in Table 2 confirm the existence of correlations between sensory analysis and the titratable acidity of the coffee, suggesting that the score of a specialty coffee correlates with the total titratable acidity.

We suggest research regarding the hypothesis that the acids present in coffee are associated with sensory perception of the coffee as judged by Q-Graders. After the treatment with the enzyme extract, the coffee showed an increase in $\mathrm{pH}$ value compared to coffee produced from traditional fermentation. Based on the results presented so far, it can be inferred that 
the TTA cannot be correlated with the type of coffee beverage (good or bad), but with the sensory characteristics that the coffee may have, as the sensory attributes transmit the guiding indications so that Q-Graders can define the quality of a product, whether good or bad.

When analyzing the correlation of TTA with phenolic compounds and $\mathrm{pH}$ with phenolic compounds, neither parameter showed significant correlation; however, the $\mathrm{pH}$ and TTA data are positively correlated (Table 3 ).

The correlation between total titratable acidity and $\mathrm{pH}$ was significant at $1 \%$ probability by the $t$-test. This result highlights a new perspective, indicating the need to monitor these variables in fermentation so that the exact moment of interruption or changes during the fermentation stages can be defined. This would assist coffee growers in controlling the quality of the coffee in the wet fermentation process.

\subsection{Hierarchical grouping of physicochemical results}

The first group is Group A, in the range of points 1 to 4 for the $1^{\text {st }}$ altitude, all the methods come together, following the same behavior observed between points 13 to 16 for the $4^{\text {th }}$ altitude, ending group A with the point 21 , referring to the $6^{\text {th }}$ altitude for the washed method.

Group B indicates the junction and formation of a group by point 17 , the 5 th altitude, washed; point 22 allocated at the 6th altitude; and the yeast fermentation method at point 23 (6th altitude), fully washed.

Finally, Group $\mathrm{C}$ is formed by points ranging from 5 to 8,2 nd altitude and all processing methods; points ranging from 9 to 12 at the 3 rd altitude with all the processes; followed by points 18 to 20 at the 5 th altitude, with the yeast fermentation, fully-washed, and semi-dry methods; and ending with point 24 at the 6 th altitude and the semi-dry method.

These results indicate that some ranges exhibit the same responses among all compounds; however, it does not indicate a standard regarding the homogeneity of physicochemical composition, thus reinforcing that the estimation techniques based on physicochemical composition should not be considered as reliable parameters for quality control.

\section{CONCLUSIONS}

The results presented show that the physicochemical structure of the coffees change due to the fermentation conditions used, indicating that these phenomena can cause a variation in sensory perceptions among the Q-Graders.

Consequently, the effects of organic acids on fermentation and sensory analysis need to be better understood, considering that titratable acidity alone is not sufficient to explain coffee quality as dependent on the amount of acid present in the sample.
Considering the processing method, we observed that the yeast fermentation, presented the highest values of phenolic compounds and total titratable acidity. We suggest that the levels of tannin and esters be quantified in this method. Finally, the $\mathrm{pH}$ showed a higher value for the washed process.

TTA and $\mathrm{pH}$ were the variables that most changed according to the method used in processing, as well as according to altitude. Thus, we propose that organic acids be quantified by HPLC to increase the discussion on the topic. The sensory variables of the SCA protocol have a positive correlation with TTA. Similarly, $\mathrm{pH}$ has a positive correlation with TTA.

Further investigations may indicate what the chemical composition of the fermentation must is and which chlorogenic acids may form during processing and fermentation to better understand the parameters associated with coffee quality.

\section{ACKNOWLEDGMENTS}

The authors thank the Instituto Federal do Espírito Santo for supporting this research and for translation and review of this article; the Q-Graders, who dedicated themselves to carrying out this study; and the Conselho Nacional de Desenvolvimento Científico e Tecnológico - CNPq (469058/2014-5) and the Secretaria de Educação Profissional e Tecnológica - SETEC of the Brazilian Ministry of Education for making resources available for the study. Thanks also to the Instituto Capixaba de Pesquisa, Assistência Técnica e Extensão Rural - Incaper and the coffee growers Reginaldo Brioschi, Nierson Barbosa, Marcos Marchioro, Waldeir Tomazini, and Joselino Meneguetti.

\section{REFERENCES}

ABRAHÃO, S. A. et al. Compostos bioativos e atividade antioxidante do café (Coffea arabica L.). Ciência e Agrotecnologia, 34(2):414-420, 2010.

ASSOCIATION OF OFFICIAL ANALYTICAL CHEMISTS - AOAC. Official methods of analysis of the association of official analytical chemists. 15th. Washington: AOAC International, 1990. 1200p.

BONILLA-HERMOSA, V. A.; DUARTE, W. F.; SCHWAN, R. F. Utilization of coffee by-products obtained from semi-washed process for production of value-added compounds. Bioresource technology, 166:142-150, 2014.

BOSSELMANN, A. S. et al. The influence of shade trees on coffee quality in small holder coffee agroforestry systems in Southern Colombia. Agriculture, Ecosystems \& Environment, 129(1-3):253-260, 2009.

CLARKE, R.; VITZTHUM, O. G. Coffee: Recent developments. $1^{\text {st }}$ ed. John Wiley \& Sons, 2008. 88p. 
CLEMENTE, A. C. S. et al. Post-harvest operations and physicochemical and sensory quality of coffees. Coffee Science, 10(2):233-241, 2015.

CORREAA, V. G. et al. Estimate of consumption of phenolic compounds by Brazilian population. Revista de Nutrição, 28(2):185-196, 2015.

DA MATTA, F. M. Exploring drought tolerance in coffee: A physiological approach with some insights for plant breeding. Brazilian journal of plant physiology, 16(1):1-6, 2004.

DE MELO, P. et al. Isolation, selection and evaluation of yeasts for use in fermentation of coffee beans by the wet process. International journal of food microbiology, 188:60-66, 2014.

DUARTE, G. S.; PEREIRA, A. A.; FARAH, A. Chlorogenic acids and other relevant compounds in Brazilian coffees processed by semi-dry and wet post-harvesting methods. Food Chemistry, 118(3):851-855, 2010.

EVANGELISTA, S. R. et al. Improvement of coffee beverage quality by using selected yeasts strains during the fermentation in dry process. Food Research International, 61:183-195, 2014a.

FARAH, A. et al. Effect of roasting on the formation of chlorogenic acid lactones in coffee. Journal of Agricultural and Food Chemistry, 53(5):1505-1513, 2005.

FERNANDES, S. M. et al. Chemical evaluation and aqueous extract of roasting coffes (Coffea arabica L.) and conilon (Coffea canephora Pierre). Ciência e Agrotecnologia, 27(5):1076-1081, 2003.

FERRÃO, M. F. et al. Técnica não destrutiva de análise de tanino em café empregando espectroscopia no infravermelho e algoritmo genético. Tecno Lógica, 7(1):9-26, 2003.

FERREIRA, G. F. P. et al. Fungos associados a grãos de café (Coffea arabica L.) beneficiados no sudoeste da Bahia. Summa phytopathologica, 37(3):98-102, 2011.

FRANCA, A. S.; MENDONÇA, J. C.; OLIVEIRA, S. D. Composition of green and roasted coffees of different cup qualities. LWT-Food Science and Technology, 38(7):709-715, 2005.

GLOESS, A. N. et al. Comparison of nine common coffee extraction methods: Instrumental and sensory analysis. European Food Research and Technology, 236(4):607627, 2013.
INTERNATIONAL COFFEE ORGANIZATION - OIC. Documents. 1992. Available in: <https://www.ico.org/ documents_e.asp>. Access in: December 20, 2020.

JOËT, T. et al. Influence of environmental factors, wet processing and their interactions on the biochemical composition of green arabica coffee beans. Food chemistry, 118(3):693-701, 2010.

LEE, L. W. et al. Coffee fermentation and flavor - An intricate and delicate relationship. Food chemistry, 185:182-191, 2015.

LIN, C. C. Approach of improving coffee industry in taiwan-promote quality of coffee bean by fermentation. The Journal of International Management Studies, 5(1):154-159, 2010.

MALTA, M. R.; SANTOS, M. L. dos.; MELO SILVA, F. A. de. Qualidade de grãos de diferentes cultivares de cafeeiro (Coffea arabica L.). Acta Scientiarum. Agronomy, 24:1385-1390, 2002.

MASOUD, W.; JESPERSEN, L. Pectin degrading enzymes in yeasts involved in fermentation of Coffea arabica in East Africa. International journal of food microbiology, 110(3):291-296, 2006

MORAIS, S. A. L. D. et al. Compostos bioativos e atividade antioxidante do café conilon submetido a diferentes graus de torra. Química Nova, 32(2):327-331, 2009.

NASANIT, R.; SATAYAWUT, K. Microbiological study during coffee fermentation of Coffea arabica var. chiangmai 80 in Thailand. Agriculture and Natural Resources, 49(1):32-41, 2015.

PEREIRA, L. L. et al. Propositions on the optimal number of Q-Graders and R-Graders. Journal of Food Quality, 3285452:1-7, 2018.

PEREIRA, L. L. et al. New propositions about coffee wet processing: Chemical and sensory perspectives. Food Chemistry, 310:e125943, 2020.

PINTO, N. A. V. D. et al. Avaliação dos polifenóis e açúcares em padrões de bebida do café torrado tipo expresso. Revista Brasileira de Agrociência, 7(3):193-195, 2001.

R CORE TEAM. R language and enviromental for statitiscal computing. R Foundation for Statistical, Vienna, Austria. 2019. Available in: <http:www.r-project.org >. Access in: December, 20, 2020.

RAMOS, P. H. et al. Produção e caracterização de carvão ativado produzido a partir do defeito preto, verde, ardido (PVA) do café. Química nova, 32(5):1139-1143, 2009. 
REINATO, C. H. R. et al. Qualidade do café secado em terreiros com diferentes pavimentações e espessuras de Camada. Coffee Science, 7(3):223-237, 2012.

RIBEIRO, B. B. et al. Avaliação química e sensorial de blends de Coffea canephora Pierre e Coffea arabica L. Coffee Science, 9(2):178-186, 2014.

SANDHYA, M. V. S. et al. Inoculum of the starter consortia and interactive metabolic process in enhancing quality of cocoa bean (Theobroma cacao) fermentation. LWT-Food Science and Technology, 65:731-738, 2016.

SCHOLZ, M. B. S. et al. Características físico-químicas de grãos verdes e torrados de cultivares de café (Coffea arabica L.) do IAPAR. Coffee Science, 6(3):245-255, 2011.

SCHOLZ, M. B. D. S. et al. Atributos sensoriais e características físico-químicas de bebida de cultivares de café do IAPAR. Coffee Science, 8(1):6-16, 2013.

SCHWAN, R. F.; FLEET, G. H. Cocoa and coffee fermentations. $1^{\text {st }}$ ed. New York: CRC Press, 2014. 401p.

SILVA, S. D. A. et al. Mapping the potential beverage quality of coffee produced in the Zona da Mata, Minas Gerais, Brazil. Journal of the Science of Food and Agriculture, 96(9):3098-3108, 2016.
SIQUEIRA, H. H. D.; ABREU, C. M. P. D. Composição físico-química e qualidade do café submetido a dois tipos de torração e com diferentes formas de processamento. Ciência e Agrotecnologia, 30(1):112$117,2006$.

SOMPORN, C. et al. Effect of shading on yield, sugar content, phenolic acids and antioxidant property of coffee beans (Coffea arabica L. cv. Catimor) harvested from north-eastern Thailand. Journal of the Science of Food and Agriculture, 92(9):1956-1963, 2012.

SPECIALTY COFFEE ASSOCIATION OF AMERICAN SCAA. Protocols. 2013. Available in: $<$ http://www.scaa. org/PDF/resources/cupping-protocols.pdf $>$. Access in: December, 20, 2020.

VELMOUROUGANE, K. Impact of natural fermentation on physicochemical, microbiological and cup quality characteristics of Arabica and Robusta coffee.

Proceedings of the National Academy of Sciences, India Section B: Biological Sciences, 83(2):233-239, 2013.

WANG, X. et al. Effects of capsule parameters on coffee extraction in single-serve brewer. Food Research International, 89:797-805, 2016. 